\title{
16. On the significance of saying 'sorry': Apology and reconciliation in Australia
}

\section{ISABELLE AUGUSTE}

As an observer of Aboriginal politics over the past ten years, I have followed closely the outcome of three federal elections wondering if a change of leadership in Australia would really result in an apology. Last year, I was privileged to witness a significant moment in Australian history. On 13 February 2008, I was on the lawns of Parliament House in Canberra, with some Aboriginal people and some other Australians, when Prime Minister Kevin Rudd said 'sorry' to the Indigenous peoples of the country.

The Australian Apology has already paved the way for other important gestures worldwide. On 6 June 2008, the Japanese Parliament, in a bipartisan motion, recognised the Ainou people as the Indigenous peoples of Japan and promised to improve their living conditions. ${ }^{1}$ A few days later, on 11 June, in another part of the world, Canadian Prime Minister Stephen Harper apologised to the Aboriginal people of the country for Canada's role in the Indian residential school system and the harm, the disastrous effects, it created. There is indeed a growing international trend to apologise for past wrongs, notably for past human rights abuses. ${ }^{2}$ An apology, nevertheless, is far from being an easy gesture nor an insignificant one, as American scholar Aaron Lazare shows in his book On Apology. It requires an individual, a group or an institution to acknowledge an offence or grievance and accept responsibility for it. An apology has a dual role. It responds, on the one hand, to the need of the victims for recognition, and on the other, it offers the offenders the opportunity to make amends for their misdeeds. ${ }^{3}$ As a sign of regret, in the political discourse in particular, it presents this ideal, of redressing past injustices and of laying a foundation for

1 'Le Japon reconnaît enfin le peuple aïnou', Libération, 4 June 2008.

2 See, for example Barkan and Karn 2006; Brooks 1999. On the political uses of official apologies in the United States, Australia, Canada and New Zealand, see Nobles 2008.

3 Lazare 2004. 
better relationships between the two parties. The dual role of the apology is exemplified in the Australian Apology. But why did Australia apologise? What was the Apology about? Why was it significant to say 'sorry'?

In this essay, I will provide some historical background to the Apology. More specifically, I will deal with the place the Apology takes in the reconciliation process and offer an account of what happened on 13 February 2008 to show its significance in the Australian context.

\section{Some background on the reconciliation process}

Reconciliation, if we look at its core definition, is derived from the Latin word 'conciliare' which means bringing together. The most basic meaning of the word is 'restoring friendly relations between'. We can also summarise reconciliation as Hamber and Kelly have in their study of Northern Ireland as a process of 'addressing conflictual and fractured relationships' ${ }^{4}$ In Australia, the conflict that opposes Indigenous Australians - the Aboriginal and Torres Strait Islander people - to the Australian settler-state finds its origins in the colonisation of the country. Australia, as we all know, is the homeland of the Aboriginal and Torres Strait Islander people. They have lived there since time immemorial, at least 40,000 years according to some scientific evidence, since the Dreaming or Dreamtime, which is the time of creation, according to their own beliefs. ${ }^{5}$ When the British arrived in 1788, the Indigenous people were dispossessed and then became subject to discriminatory policies of segregation and assimilation. More recently, Australia, like other settler societies such as Canada, has attempted to adopt a new relationship with its Indigenous population. As Short says, 'the peacemaking language of Reconciliation has been the preferred rhetorical device for such endeavour' in those countries. ${ }^{6}$

In Australia, the 1967 Referendum can be considered as the starting point of reconciliation. On 27 May 1967, a referendum was held in order to amend two sections of the Constitution considered discriminatory to Aboriginal people. Many myths surround that event, as historians Andrew Markus and Bain Attwood have argued in their book The 1967 Referendum or when the Aborigines did not get the Vote (1997). The 1967 Referendum per se was not about citizenship rights such as voting rights as we could still read in some Australian newspapers in 2007. It was about repealing section 127, which reads: 'in reckoning the numbers of the people of the Commonwealth or of a State or other part of the Commonwealth, Aboriginal natives shall not be counted', and amending section 51 (26) to give powers to the Commonwealth to legislate for

\footnotetext{
Hamber and Kelly 2004.

Broome 1994: 9-10; Kohen 1993: 3; Willmot 1987: 9.

Short 2005: 267.
} 
Aboriginal people. It is true that the reformists of the 1960s, notably FCAATSI, the Federal Council for the Advancement of Aborigines and Torres Strait Islanders, which had fought for more than ten years for such a referendum to take place, had transformed the 'Yes Vote' into a campaign for equal rights, for the end of discrimination, better conditions of life and full citizenship for Aboriginal people. This is probably what they expected would result as they believed that federal control of Aboriginal Affairs would be beneficial to the Aboriginal people in the country. Nevertheless, whether one voted for one reason or another, people became aware there was a wrong to be put right and what makes the event significant is the symbol of changes it represents. The least one can say is that FCAATSI and their supporters brilliantly succeeded in rallying the Australian population to the Aboriginal cause. Indeed, a massive 90 per cent of the population voted 'yes' to the 1967 Referendum. ${ }^{7}$ This sweeping vote should have put strong pressure on the Commonwealth government to act as it was expected to play a much greater role in Aboriginal Affairs. But, the changes were slow and it was not until 1972 and the election of a new Labor government headed by Gough Whitlam that the Aboriginal cause became a national issue and new measures were introduced as part of a self-determination policy. This marked the beginning of a new approach in Indigenous Affairs in Australia and a new period which saw the development of some land rights policies, the creation of some Aboriginal-specific structures and the elaboration of some special socio-economic programs at the federal level.

The word reconciliation itself did not actually appear in political discourse until 1983 when Minister for Aboriginal Affairs Clyde Holding stated in his presentation of the Labor program to Parliament that there should be some form of reconciliation by the bi-centenary of the colonisation of the country. He did not give further explanation of what it meant, nor how to get there, nor the form it should take. ${ }^{8}$ In 1988, nothing came out but some Aboriginal protests in Sydney where the motto was, 'We have survived'. Prime Minister Robert Hawke did promise then to sign a Treaty with Aboriginal people, ${ }^{9}$ and it is arguable that the formal process of reconciliation that his government set up was a way to delay the whole issue. In the meantime the end of the 1980s were marked by a number of inquiries highlighting the plight of Aboriginal people. Notably, the Royal Commission into Aboriginal Deaths in Custody (RCIADIC) became one of the most extensive inquiries conducted on the conditions of Aboriginal people in Australia. Among the 339 recommendations, Commissioner Johnston put forward the idea that 'the reconciliation of the Aboriginal and non-Aboriginal communities must be an essential commitment of all sides if change is to be

7 Auguste 2008: 41-44.

8 Holding 1983: 3487.

9 See the 'Barunga Statement' of 1988 which is now hung in Parliament House. 
genuine and long term' ${ }^{10}$ Robert Tickner, the third of Bob Hawke's Ministers for Aboriginal Affairs, is the one who formalised this notion of reconciliation. He managed to obtain support from some Aboriginal organisations and from the opposition for his project. ${ }^{11}$ And for the first time in eight years of Labor government, a legislation concerning Aboriginal people passed with bipartisan support. ${ }^{12}$ The Council for Aboriginal Reconciliation Act was voted in 1991 and set up an organisation comprising some Aboriginal representatives and some delegates of different political affiliations to promote reconciliation for ten years. The Council for Aboriginal Reconciliation (CAR), first headed by Patrick Dodson, envisioned for the centenary of Federation, the anniversary of the Australian nation, 'a united Australia which respects this land of ours; values the Aboriginal and Torres Strait Islander heritage and provides justice and equity for all' ${ }^{13}$ This was the beginning in Australia of a formal process of reconciliation.

The issue of an Apology became associated with the reconciliation process six years afterwards with the release of a report on the Stolen Generations.

\section{Stolen Generations, Apology and reconciliation 'off-track'}

In the words of Peter Read who coined the term with Jay Arthur:

We Stolen Generations are the victims of Australia-wide policies which aimed to separate us from our parents, our family, our neighbourhood, our community, our country and our rightful inheritance as Aboriginal citizens of Australia.

We are the victims of a policy which - if it had been successful - would have put an end to Aboriginality forever. Not just ours - everyone's. And we are still hurting. ${ }^{14}$

The issue of forcible removal, already condemned in the 1920s by Fred Maynard and the Australian Aboriginal Progressive Association, ${ }^{15}$ was not much talked about in the 1980s when the pamphlet on the Stolen Generations was released and when its authors Peter Read and Coral Edwards set up Link-Up, an association to help reunite families. But a growing awareness of it emerged. In presenting the policy of the Hawke government in 1983, Minister for Aboriginal Affairs Clyde Holding referred to the deliberate policy of governments to separate children

10 Royal Commission into Aboriginal Deaths in Custody 1991: recommendation 339, chapter 38.

11 This does not mean that there was no opposition to the process of reconciliation. For some comments, see for example Moores 1995.

12 Tickner 2001: chapter 2.

13 Council for Aboriginal Reconciliation 1994: viii.

14 Read 1999: xi.

15 Attwood and Markus 1999: 66-67. 
from their families with a view to assimilating them, and promised to 'restore the rights of Aboriginal families to raise and protect their own children' ${ }^{16}$ In 1991, The Royal Commission Into Aboriginal Deaths In Custody showed that among the 98 cases studied, 43 persons had been separated from their families. ${ }^{17}$ In 1995, the Keating government finally set up an inquiry because of an 'increasing concern that the general public's ignorance of the history of forcible removal was hindering the recognition of the needs of its victims and their families and provision of services' ${ }^{18}$

The inquiry was conducted by Human Rights and Equal Opportunity Commission President Sir Ronald Wilson and by Aboriginal and Torres Strait Islander Social Justice Commissioner Mick Dodson whose mission was to trace the history of separation past and present, but also to examine principles for compensation. As the inquirers stated, it is 'no ordinary report'. It goes to the heart of personal stories, testimonies of separation, institutionalisation, abuses and denigration. Five-hundred and eighty-five Aboriginal persons courageously came forward to talk about their painful experiences, a violation of their human rights that the inquirers compared to an act of genocide. It was not only established that this practice of forcible removal began with colonisation but that it was still happening in the 1970s. No Indigenous family seems to have escaped from its effects. ${ }^{19}$

It is from the disturbing findings of this particular inquiry that a call for an apology emerged. An acknowledgement from the perpetrators of the wrongs separation caused and an apology to the victims and their families were seen as central to a healing process. The Commission received many submissions along these lines. For the Commission, 'the first step in any compensation and healing for victims of gross violations of human rights must be an acknowledgement of the truth and the delivery of an apology'. This apology was also seen as an elementary condition of and a first step towards reconciliation. ${ }^{20}$

The Bringing Them Home Report was released in May 1997 while the Council for Aboriginal Reconciliation was holding a major convention in Melbourne. The convention, as Sir Ronald Wilson stated, had the effect of merging the two issues of reconciliation and the stolen generation into one. ${ }^{21}$ The issue of an Apology became inextricably intertwined with the process of reconciliation from then on. Bringing to light this hidden aspect of Australia's history caused dismay and there was a massive positive response from State Parliaments, Churches,

16 Holding 1983: 3486.

17 Royal Commission into Aboriginal Deaths in Custody 1991: para 2.2.9.

18 Human Rights and Equal Opportunity Commission 1997: introduction.

19 Human Rights and Equal Opportunity Commission 1997: introduction.

20 Human Rights and Equal Opportunity Commission 1997: chapter 14.

21 Wilson 1998. 
community groups, ethnic organisations and local governments that supported the stance of apologising. ${ }^{22}$ Since the first Sorry Day in 1998, thousands of people have signed sorry books across the country to express their grievances. ${ }^{23}$

By contrast, the Howard government refused to formally apologise. It ignored the recommendations of an apology and compensation when it responded to the Bringing Them Home Report in December 1997. ${ }^{24}$ Before the federal election of 1998, Howard explained that his motives did not involve a fear of compensation but a belief that, if you express regrets for things, 'you are collectively and in a direct sense responsible', and he did not think 'that applies to the current generation of Australians' ${ }^{25}$ In that sense, he was faithful to a position he had taken on Indigenous issues when he was leader of the opposition in the 1980s: 'guilt is not hereditary'. In August 1999, he did move a motion in which he expressed his deep and sincere regret 'that Indigenous Australians suffered injustices under the practices of past generations'.$^{26}$ But his motion and his speech did not even mention the Stolen Generations and it was not the long awaited formal apology. In May 2000 when CAR released the Documents of Reconciliation, John Howard responded with his own version of reconciliation in which he excluded the Apology. Those documents CAR developed in the course of its three mandates, in consultation with the Australian population, provide a definition of reconciliation for Australia.

The Australian Declaration Towards Reconciliation, which has the touch of writer David Malouf and historian Jackie Huggins, is a strongly worded document offering a vision of a reconciled Australia. It refers in particular to the need to recognise Aboriginal people as the Indigenous component of Australia - their unique status, their cultural identity, the necessity to sign a treaty, a recognition of past mistreatment, and the right to self-determination within the life of the nation. This Declaration is supported by a Road Map to Reconciliation embracing four National Strategies: to sustain the reconciliation process, to recognise Aboriginal and Torres Strait Islander Rights, to achieve Economic Independence, and to overcome Disadvantage. The Strategies include symbolic as well as practical actions to respond to the 'unfinished business' of reconciliation and are addressed to all levels of government, to the private sector, and to the community at large. And to give effect to these actions, CAR called in its last annual report for a Constitutional reform to recognise and protect the specific status of Aboriginal people in Australia. ${ }^{27}$

\footnotetext{
Dodson 1997.

National Sorry Day Committee 2008.

Herron 1997.

Quoted in Read 1999: ix.

Howard 1999: 9205.

Council for Aboriginal Reconciliation 2000: recommendation 5-6.
} 
It is, however, this idea that Aboriginal people can have special rights because of their indigeneity which has been most problematic. As in 1967, there was another massive popular response to reconciliation, exemplified in May 2000 in the Sydney Harbour Bridge walk, gathering together a quarter of a million of Australians. Nevertheless, the government response did not follow. In December 2000 when he received the final report of CAR from Evelyn Scott, second and final chair of the Council, Prime Minister Howard stated that he would consider the recommendations of the Council but that his position on some points was unchanged. ${ }^{28} \mathrm{He}$ did not have to be more precise and he was not. John Howard had made his position clear on Indigenous issues in the 1980s when he was leader of the opposition on such matters as a Treaty, self-determination, and 'inter-generational guilt'. ${ }^{29}$ And he kept to this line when he became Prime Minister in 1996. Throughout his mandate, he repeated in a number of motions his commitment to genuine reconciliation. ${ }^{30}$ Nevertheless, his government and the Liberal Party had a different vision of reconciliation from CAR. They made a distinction between the practical and what they referred to as the symbolic. The practical is about overcoming disadvantage and true reconciliation for them was limited to a socio-economic issue. The symbolic embraced anything to do with the recognition of the Aboriginal as the Indigenous component of Australia and a recognition of past mistreatment - in other words, the Apology. As a result, the reply of the government to the recommendations made by CAR was not surprising. In the Commonwealth Response, all the recommendations dealing with special rights were not considered by the government whose focus was on 'practical reconciliation'. There is a sentence which is quite significant:

The Prime Minister indicated at the time of release of the Declaration that though there were significant areas of agreement, the Government could not give its full support. Consequently, on May 11th 2000, the Government presented a revised Declaration to which it offered its full support. ${ }^{31}$

In other words, they were in favour of reconciliation but on their own terms. What may be surprising is the time the government took to give its answer. The Aboriginal and Torres Strait Islander Social Justice Commissioner Bill Jonas was among those who expressed concern about the slowness of the government response to the documents. In his Social Justice Report of 2001, he recommended that the matter be inquired into. ${ }^{32}$ It was at the genesis of the Senate Legal and

28 Howard 2000.

29 Liberal Party of Australia 1988: 96.

30 See for example Howard 1996: 6155, 1999: 9205.

31 Commonwealth Government 2002: recommendation 2.

32 Aboriginal and Torres Strait Islander Social Justice Commissioner 2001: recommendation 11. 
Constitutional References Committee inquiry which started in August 2002, a month before the answer of the government. The title of the report says it all: Reconciliation Off Track. The first page gives the thrust of the inquiry:

This inquiry has clearly established that the Commonwealth Government's practical reconciliation approach is failing Indigenous people. Indicators of Indigenous disadvantage are not improving in many areas. There has been a very minimal response to the symbolic issues outlined by the Council for Aboriginal Reconciliation. There is no legislation to enact a treaty process and no timeframe or process to resolve 'unfinished business'. The Government's emphasis on areas of perceived agreement leaves many important issues off the agenda, to the detriment of Indigenous people. In short, there is a failure of national leadership on this, one of the most critical issues in the definition of the nation. ${ }^{33}$

The organisers recognised the work done by many agencies for reconciliation, in particular Reconciliation Australia (RA), the foundation which took over the mission of CAR in 2001. ${ }^{34}$ Overall for the committee, however, 'the process is now off track. There is a sense that momentum is being lost. People are becoming disheartened and reconciliation is slipping off the national agenda' ${ }^{35}$

The 40th anniversary of the 1967 Referendum in 2007 echoed this dismay. It was a bittersweet commemoration. The veterans of the referendum campaign expressed mixed feelings about achievements since the 1960s. For Faith Bandler, there have been changes which cannot be denied:

Of course there have been some changes as a result of [the 1967 Referendum]. No one can possibly dispute it. Before that, the people were just locked away on reserves, deprived of a voice to speak out by whoever controlled the reserve, usually one white person. It was a grim situation. ${ }^{36}$

But for an angry Lowitja O'Donoghue, 'conditions for Aboriginal people are not improving but going backward' ${ }^{37}$ I will not try here to compare the situation of Aboriginal people in the 1960s and today, I have done it elsewhere. ${ }^{38}$ The least one can say is that the condition of Aboriginal people is deplorable compared to other Australians. This was dealt with for instance in a report by the National

\footnotetext{
Senate Legal and Constitutional References Committee 2003: v. Senate Legal and Constitutional References Committee 2003: chapter 3. 
Aboriginal Community Controlled Health Organisation and Oxfam which came out before 27 May. ${ }^{39}$ The focus has notably been on health, on closing the 17year life expectancy gap.

For a more balanced view of the past 40 years we can turn to Mick Dodson and Fred Chaney from Reconciliation Australia:

Forty years of reconciliation can at best be described as having mixed outcomes. If reconciliation is about developing a relationship that works better between Aboriginal and Torres Strait Islander peoples and other Australians, if it's about ending indigenous disadvantage, we have certainly not achieved it ... On the other hand, it's important in this anniversary year that we recognise and build on developments that could not have been imagined 40 , or even 20 years ago. ${ }^{40}$

Such hopes were expressed before 21 June. That day, Prime Minister Howard and Minister for Indigenous Affairs Mal Brough called a special press conference to announce a national Emergency Intervention in the Northern Territory. This was officially to respond to the Little Children are Sacred report made public a few days before. ${ }^{41}$ The Commonwealth government accused the Northern Territory government of reacting too slowly to this report bringing to light some serious issues of child abuse in communities, and decided to interfere in their jurisdiction. No one could of course argue against the gravity of the matter. But some scepticism arose about the motives of the government. Why has child abuse and violence in communities become an emergency issue all of a sudden when numerous reports over the years have called for action? What has the scrapping of the Permit System allowing the Aboriginal people of the Northern Territory to control access to their land to do with responding to the problem ${ }^{42}$ These were among the first questions to emerge and they were dealt with extensively in the Senate when the government decided to enshrine its measures into laws two months later. At that time, words such as 'paternalism' and assimilation were aired without reserve.

To describe the intervention, Jon Altman and Melinda Hinkson have used the notion of 'coercive reconciliation' as the title of a book which came out in October 2007. Australia then appeared to be going backward in her relationship with her Indigenous people at a particular time when the Declaration on the Rights of Indigenous Peoples was voted at the United Nations Assembly -

39 National Aboriginal Community Controlled Health Organisation and Oxfam Australia 2007.

40 Dodson and Chaney 2007.

41 Wild and Anderson 2007.

42 See for example a special edition of Living Black, SBS Television, 8 July 2007. 
Australia being one of the four countries to vote against it. Nevertheless, the federal election which took place on 24 November 2007 brought some new prospects for reconciliation in Australia with the promise of an apology.

\section{Sorry - a first step towards reconciliation?}

ALP candidate Kevin Rudd promised, like his predecessors, to apologise to the Stolen Generations if elected. Right after the election, on 26 November, the new Prime Minister Rudd announced that an apology would be delivered at the next sitting of Parliament. The official date was known at the end of January as well as the absence of compensation. On 12 February, the 42nd Parliament was sworn in, after an Aboriginal ceremony. It was the first time in Australian History that Aboriginal people had taken part in the opening of Parliament. The following day, 'sorry' resonated throughout the country.

Thousands of people, Aboriginal and non-Aboriginal, Australians and nonAustralians, had gathered in the main square of capital cities, in the outback, or on the lawns of Parliament. Others followed the event on television or on the radio. Some even woke up in the middle of the night overseas to watch the Apology on the internet. It was a really emotional moment. Many had travelled by bus from as far away as the Northern Territory to be in the capital city for the first time. Many Aboriginal persons thought an Apology would never happen in their lifetime. Some brought with them pictures of family members who did not have that chance.

According to Aaron Lazare, the success or failure of an apology depends on four major components: the acknowledgement of the offence, the explanation, the expression of shame and remorse, and reparation. ${ }^{43}$ Kevin Rudd's Apology contains those ingredients. Rudd began his speech by relating a personal story, that of Nana Fejo, a member of the Stolen Generation. It was a way for him to put his words into context and explain that he was not talking about 'intellectual curiosities' but human beings, human lives. He then explained the significance of the moment for those still in doubt, for his opponents, for everyone. He was cautious in the way he acknowledged the offence. In 2000, a survey commissioned by CAR found that 40 per cent of Australians agree and 53 per cent disagree that, 'On behalf of the community, governments should apologise to Aboriginal people for what happened in the past' ${ }^{44}$ Rudd specified that those individuals who implemented the laws were not responsible. Those who were responsible were governments and the Parliament of the nation in what was one of the 'darkest chapters of Australia's history: the forced removal of Aboriginal children on racial grounds':

43 Lazare 2004.

44 Newspoll 2000 
Therefore, for our nation, the course of action is clear, and therefore, for our people, the course of action is clear: that is to deal now with what has become one of the darkest chapters in Australia's history. In doing so, we are doing more than contending with the facts, the evidence and the often rancorous public debate. In doing so, we are also wrestling with our own soul. This is not, as some would argue, a black-armband view of history; it is just the truth: the cold, confronting, uncomfortable truth - facing it, dealing with it, moving on from it. Until we fully confront that truth, there will always be a shadow hanging over us and our futures as a fully united and fully reconciled people. It is time to reconcile. It is time to recognise the injustices of the past. It is time to say sorry. It is time to move forward together. ${ }^{45}$

A jubilant crowd applauded at the first sorry. It was amplified when in a powerful manner the Prime Minister addressed his direct apologies to the Stolen Generations and detailed the hurt caused, recalling Prime Minister Keating in his Redfern Speech in 1992:

To the stolen generations, I say the following: as Prime Minister of Australia, I am sorry. On behalf of the government of Australia, I am sorry. On behalf of the Parliament of Australia, I am sorry. I offer you this apology without qualification. We apologise for the hurt, the pain and suffering that we, the parliament, have caused you by the laws that previous parliaments have enacted. We apologise for the indignity, the degradation and the humiliation these laws embodied. We offer this apology to the mothers, the fathers, the brothers, the sisters, the families and the communities whose lives were ripped apart by the actions of successive governments under successive parliaments. In making this apology, I would also like to speak personally to the members of the stolen generations and their families: to those here today, so many of you; to those listening across the nation - from Yuendumu, in the central west of the Northern Territory, to Yabara, in North Queensland, and to Pitjantjatjara in South Australia. ${ }^{46}$

Rudd recognised the difficulty of forgiveness but called for reconciliation and a new beginning, putting forward a number of proposals for the future, even taking Brendan Nelson, the leader of the opposition, by surprise in calling for a joint-policy commission.

Nelson was of course in an uncomfortable position if we consider the line taken by his party in the previous ten years. Nevertheless, despite some obvious dissensions, the coalition offered its in-principle support at the beginning of 
February and on 13 February, Brendan Nelson stood up to 'speak strongly in favour of the motion'. Nelson, however, while recognising the hurt suffered by Aboriginal people, tried to justify the policies of the time. His decision to repeat numerous times words such as 'good intentions' or 'rescued' was not well received. It added to the pain of some who were listening to him. Tears of joy were replaced by tears of sadness. In the crowd I was in I saw many aunties bursting into tears. Anger also arose.

Talking to people afterwards, I realised that many who watched the event on television thought that the crowd turned their back on the opposition leader right from the start without even listening, an impression created by the news reports. This was not the case. After a while Nelson's speech became so unbearable for many that they turned their back to the screens as occurred in Canberra, or they chose to leave. In Perth, they switched off the television.

Nevertheless, as Tom Calma, Aboriginal and Torres Strait Islander Social Justice Commissioner, said, what is to be remembered of that historic day is that:

It's the day our leaders - across the political spectrum - have chosen dignity, hope and respect as the guiding principles for the relationship with our first nations' peoples;

Through one direct act, Parliament has acknowledged the existence and the impacts of the past policies and practices of forcibly removing Indigenous children from their families;

And by doing so, has paid respect to the Stolen Generations. For their suffering and their loss. For their resilience. And ultimately for their dignity. ${ }^{47}$

The image of the Prime Minister and the leader of the opposition walking hand in hand towards the members of the Stolen Generations is the image that will remain. To the 'sorry', some Aboriginal people have responded with tears of joy and 'thanks', 'apologies accepted', through the shirts they were wearing.

Forty-one years after the 1967 Referendum, eleven years after the Bringing Them Home report, seven years after the end of the Council for Aboriginal Reconciliation, Australia apologised to her Indigenous population for past mistreatments. Like an echo of the Declaration of Reconciliation, we could say that one part of the nation apologised and expressed its sorrow and sincere regret for the injustices of the past, while the other part accepted the apologies and forgave. This picture is ideal and can even be perceived as naïve. The 
Apology was nonetheless significant - if not for everyone, it was at least, and importantly, meaningful for those Stolen Children and their families who were waiting for some acknowledgement of what had occurred.

The Apology of course cannot be and was not meant to be the panacea for the problems affecting the Indigenous peoples of Australia. Nevertheless, it signalled some changes in Indigenous Affairs policy in the country. It had, in particular, the effect of putting the idea of reconciliation 'back on track'. Considering that the Documents of Reconciliation are also part of the many electoral promises of the Australian Labor Party, ${ }^{48}$ there remains another problematic and controversial issue raised at the 2020 Summit: the Treaty. ${ }^{49}$ Together with 'sorry', it was referred to in the press in 2000 as the 'other dirty word' the government would never agree on. ${ }^{50}$ If 'sorry' was the first step, can the Treaty be the final one?

\section{References}

Aboriginal and Torres Strait Islander Social Justice Commissioner 2001, Social Justice Report 2001, Human Rights and Equal Opportunity Commission, Sydney.

Altman, Jon and Melinda Hinkson (eds) 2007, Coercive Reconciliation, Stabilise, Normalise, Exit Aboriginal Australia, Arena Publications Association, Melbourne.

Attwood, Bain and Andrew Markus 1997, 1967 Referendum or when Aborigines did not get the vote, Aboriginal Studies Press, Canberra.

— 1999, The Struggle for Aboriginal Rights, A Documentary History, Allen \& Unwin, Sydney.

Auguste, Isabelle 2008, L'administration des Affaires Aborigènes en Australie depuis 1972: l'autodétermination en question, l'Harmattan (Collection Lettres du Pacifique), Paris.

Australian Government 2008, 2020 Summit, accessed 11 August 2009: <http:// www.australia2020.gov.au>

Australian Labor Party 2007, 44th National Conference, Aboriginal and Torres Strait Islanders, accessed 11 August 2010: <http://www.alp.org.au/platform/ chapter_13.php>

48 Australian Labor Party 2007: section 48.

49 Australian Government 2008.

50 Jopson 2000. 
Barkan, Elazar and Karn Alexander (eds) 2006, Taking Wrongs Seriously: Apologies and Reconciliation, Stanford University Press, Stanford.

Brooks, Roy (ed) 1999, When Sorry isn't Enough: The Controversy over Apologies and Reparations for Human Injustice, New York University Press, New York.

Broome, Richard 1994, Aboriginal Australians: Black Response to White Dominance 1788-1994, 2nd edn, Allen \& Unwin, Sydney.

Calma, Tom 2008, 'Let the healing begin - response to government to the national apology to the Stolen Generations', Members Hall, Parliament House, Canberra, 13 February 2008.

Commonwealth Government 2002, Response to the Council for Aboriginal Reconciliation Final Report - Reconciliation: Australia's Challenge, AGPS, Canberra.

Council for Aboriginal Reconciliation 1994, Walking Together, the First Steps - Report of the Council for Aboriginal Reconciliation 1991-1994, AGPS, Canberra.

- 2000, Reconciliation: Australia's Challenge-Final Report to the Prime Minister and the Commonwealth Parliament, available at: <http://austlii.edu.au/au/ other.IndigLRes/car/2000/16>

Dodson, Michael 1997, 'We all bear the cost if apology is not paid', The Age, 18 December 1997.

- and Fred Chaney 2007, 'The stage is set for closing the gap', The Weekend Australian, 5-6 May 2007, The Inquirer.

Hamber, B And G Kelly 2004, 'Reconciliation: a working definition', Democratic Dialogue, accessed 10 May 2010: <http:/www.democraticdialogue.org>

Herron, John 1997, 'Bringing Them Home': Commonwealth initiatives, Press Release, Minister for Aboriginal and Torres Strait Islander Affairs, 16 December 1997.

Holding, Clyde 1983, 'Aboriginal Affairs', Commonwealth Parliamentary Debates: 3485-3494.

Howard, John 1996, 'Racial Tolerance', Commonwealth Parliamentary Debates: 6155.

- 1999, 'Motion of Reconciliation', Commonwealth Parliamentary Debates: 9205. 
- 2000, 'Address at the presentation of the final report to Federal Parliament by the Council for Aboriginal Reconciliation', Canberra, 7 December 2000.

Human Rights and Equal Opportunity Commission (HREOC) 1997, Bringing Them Home: National Inquiry Into the Separation of Aboriginal and Torres Strait Islander Children from their Families, HREOC, Canberra.

Jopson, Debra 2000, 'The other dirty word', Sydney Morning Herald, 3 June 2000.

Kohen, Jim 1993, The Dharug and Their Neighbours, Dharug Link and Blacktown Historical Society, Sydney.

Lazare, Aaron 2004, On Apology, Oxford University Press, New York.

Liberal Party of Australia 1988, Future Directions - It's Time for Plain Thinking, The Parties, Canberra.

Moores, Irene (comp) 1995, Voices of Aboriginal Australia: Past, Present and Future, Butterfly Books, Springwood.

National Aboriginal Community Controlled Health Organisation and Oxfam Australia 2007, Close the Gap, Solutions to the Indigenous Health Crisis facing Australia, a Policy Briefing, Oxfam, Melbourne.

National Sorry Day Committee 2008, accessed 10 May 2010: <http://www.nsde. org.au>

Nelson, Brendan 2008, 'Apology to Australia's Indigenous peoples', accessed 10 May 2010: <http://www.aph.gov.au/house/Nelson_speech.pdf>

Newspoll 2000, 'Quantitative Research into Issues Relating to a Document of Reconciliation', prepared for the Council for Aboriginal Reconciliation, accessed 10 May 2010: <http:/www.austlii.edu.au/au/other/IndigLRes/ car/2000/3/quant.pdf>

Nobles, Melissa 2008, The Politics of Official Apologies, Cambridge University Press, Cambridge.

Read, Peter 1999, A Rape of the Soul so Profound: The Return of the Stolen Generations, Allen \& Unwin, Sydney.

Rintoul, Stuart 2007, 'Veterans of the referendum campaign look back with mixed feeling', The Weekend Australian, 19-20 May 2007, The Inquirer.

Royal Commission Into Aboriginal Deaths in Custody 1991, National Report, AGPS, Canberra. 
Rudd, Kevin 2008, 'Apology to Australia's Indigenous peoples', accessed 10 May 2010: <http://www.aph.gov.au/house/rudd_speech.pdf>

Senate Legal and Constitutional References Committee 2003, Reconciliation Off Track, the Senate, Canberra.

Short, Damien 2005, 'Reconciliation and the problem of internal colonialism', Journal of Intercultural Studies 26(3): 267-282.

Tickner, Robert 2001, Taking a Stand, Land Rights to Reconciliation, Allen \& Unwin, Sydney.

Wild, Rex and Patricia Anderson 2007, Ampe Akelyernemane Meke Mekarle 'Little Children are Sacred', a Report of the Northern Territory Board of Inquiry into the Protection of Aboriginal Children from Sexual Abuse, Northern Territory Government, Darwin.

Willmot, Eric 1987, Australia: The Last Experiment, ABC Boyer Lectures, Sydney.

Wilson, Ronald (Sir) 1998, 'Native Title and Reconciliation: a People's Movement', an address to the nation, National Press Club Canberra. 